DOI https://doi.org/10.18551/rjoas.2017-12.43

\title{
LOCAL CUSTOM VALUES AS NORTH LOMBOK COASTAL AREA MANAGEMENT
}

\author{
Hilmawan Arif* \\ Graduate Program in Aquaculture, Faculty of Fisheries and Marine Sciences, \\ University of Brawijaya, Indonesia \\ Marsoedi, Susilo Edi, Rudianto \\ Faculty of Fisheries and Marine Sciences, University of Brawijaya, Indonesia \\ *E-mail: arif.melonk@gmail.com
}

\begin{abstract}
The Indonesian traditional local custom known as the Ulayat is a local community right to manage certain surrounded land or water for marine natural resources management. There is recognition that the existence of customary law in Indonesia, especially concerning the fisheries and marine resources management system, is of the important and strategic value of the national effort to support sustainable marine and fisheries resources management. The aims of this research are: to identify the perceptions and aspirations of society toward Local Custom values and the adherence to the prevailing traditional/customary law, and to identify the extent to which opportunities for Local Custom values empowerment can be preserved and utilized in managing the coastal areas in North Lombok. This research uses a case study method (Yin, 2011) and qualitative analysis method. The sampling method is being collected purposively. The research results showed that the perceptions and aspirations of society toward the Local Custom values (called awig-awig) is still very strong and is still being practiced. Society tends to be more convinced that the law enforcement using customary law is more effective and has a strong deterrent effect because there are clear sanctions and prohibitions. It is due in part to distrust of the formal law, which seems arbitrary in pursuing any prosecution. The Local Custom, tradition, and customary law, as well as traditional institutions in North Lombok Regency, have an opportunity to be preserved and further developed by implementing awig-awig.
\end{abstract}

\section{KEY WORDS}

Local custom value, awig-awig, coastal area, management.

The Indonesian traditional local custom is known as the Ulayat ${ }^{1}$ rights, in this case, the ulayat rights to manage certain surrounded land or water for marine natural resources management (aquatic) (Satria \& Adhuri, 2010). This tradition still exists and is practiced by a certain part of members even though there is pressure from modern marine and fisheries management. Some of traditional systems which are still preserved and practiced, e.g. the Sasi tradition ${ }^{2}$ in Maluku, Panglima Laot $^{3}$ in Aceh and Awig-awig ${ }^{4}$ in North Lombok (Wahyudin, 2004)

Moreover, there is recognition that the existence of customary law in Indonesia, especially concerning the fisheries and marine resources management system, is an important and strategic asset for the national effort to support sustainable marine and fisheries resource management (Steebergen, 2016). However, Local Custom values in several regions in Indonesia have recently declined because of the government's policy of developing the coastal areas partially in a top-down manner, which often does not reflect the

\footnotetext{
${ }^{1}$ A legal term connoting communal rights of an (ethnic) community to land based on that community's customary law.

${ }^{2}$ Conservation system in some regional regency in Indonesia, such as in Maluku, Raja Ampat, etc. or indigenous traditions that supports sustainable.

${ }^{3}$ Acehnese Language term which means sea commander

${ }^{4}$ Set of regulations that manages the relationship between human and nature, especially in the coastal and marine areas.
} 
interests and needs of local society, and its implementation fails to utilize the existing potential resources optimally, including the traditional or Local Custom values (Stanis, 2005). The aims of this research are as follows: a) to identify the perceptions and aspirations of society toward Local Custom values and the adherence to the prevailing traditional/customary law. b) to identify the extent to which opportunities for Local Custom values empowerment can be preserved and utilized in formulating the management of coastal areas.

\section{METHODS OF RESEARCH}

The focus area of this research was on North Lombok Regency, Indonesia, consisting of five subdistricts, namely Bayan, Kayangan, Gangga, Tanjung, and Pemenang. The method used in this research was a case study and the data was analyzed qualitatively. A case study is a social science research method concerning an object which is conducted by the local guidelines. The case study is an appropriate strategy only if the researchers have little opportunity to control the events being investigated, and if their research focus is on real life contemporary phenomena, in which the limitations between phenomenon and context do not appear clearly; and in case where multi-source of evidence to be utilized (Yin, 2011). The source of data used in this research consists of primary data and secondary data. The primary data collection process was conducted through interviews with local public figures purposively. The secondary data was obtained from texts related to awig-awig.

\section{RESULTS OF STUDY}

Based on the history of North Lombok, before the arrival of Islam in the early sixteenth century, there was already a kingdom influenced by Buddhism and Hinduism. One can still see signs of the influence of two kingdoms, Majapahit and Anak Agung Karang Asem.

The history of North Lombok at that time shows that there were already the governmental and decentralization systems known as Paer Daya. The Paer itself is defined as the one region based on the area, local knowledge, and local custom.

The mangku-mangku in the traditional socio-politics customary structure is divided according to the duty, authority, and territory-based authority into three categories of kemangkuan territories, namely:

- The people who are responsible for forestry affairs and its management called Mangku Alas;

- The people who are responsible for agricultural affairs and its management called Mangku Gumi;

- The people who are responsible for the sea affairs and its management called Mangku Segara.

The relationship between the mangku and the management system showed that there was a pattern of harmonious relationship in managing natural resources by emphasizing sustainable and responsible upstream and downstream management patterns. In this context of sea and fisheries resources management, society in North Lombok at that time managed the existing resources with the wisdom deriving from ancient values and maintained them from generation to generation.

Awig-awig not only regulates about management but also the sanctions for perpetrators of vandalism. For instance (Hilmawan, 2012):

(1) If it is found and proved that suspects have used blast fishing and potassium cyanide fishing or fishing with any other toxic materials, the suspects are to be arrested by a group of fishermen and then ordered by the authorities in the respective sub-district areas to sign an affidavit not to repeat such actions or face the maximum financial penalty of Rp $10,000,000.00$ as well as to release the catch back to its habitat. (For an example of affidavit, see appendix)

(2) If the suspects commit the same crime for the second time, a group of fishermen will arrest the suspects and then destroy or burn their equipment. 
(3) If the suspects commit the same crime for the third time and it is proved, the group of fishermen will beat the suspects to death.

Awig-awig regulates both the prohibitions and sanctions for the fisheries resources and for fishermen themselves. Some examples of prohibitions include: (1) It is prohibited to go fishing on Fridays because the day is deemed a holy day; (2) if one of the fishermen dies, that day is prohibited to fishing; (3) it is prohibited to bring home the fish accompanied by the nets, the fabrics or the sarongs.

To maintain awig-awig, an organization named Fishermen Dialogue Institute of North Lombok (LMNLU) that is an affiliation of fishermen group of North Lombok, has been formed (Solihin et al, 2007). In doing their duties, LMNLU has created a community group of supervisors (Pokmaswas) in each district in the North Lombok Regency by involving fishermen (LMNLU, 2011). The duty of Pokmaswas group itself is to supervise and enforce awig-awig. Figure 1 shows the violations committed by suspects of awig-awig in accordance with the point 2 regarding the sanctions.

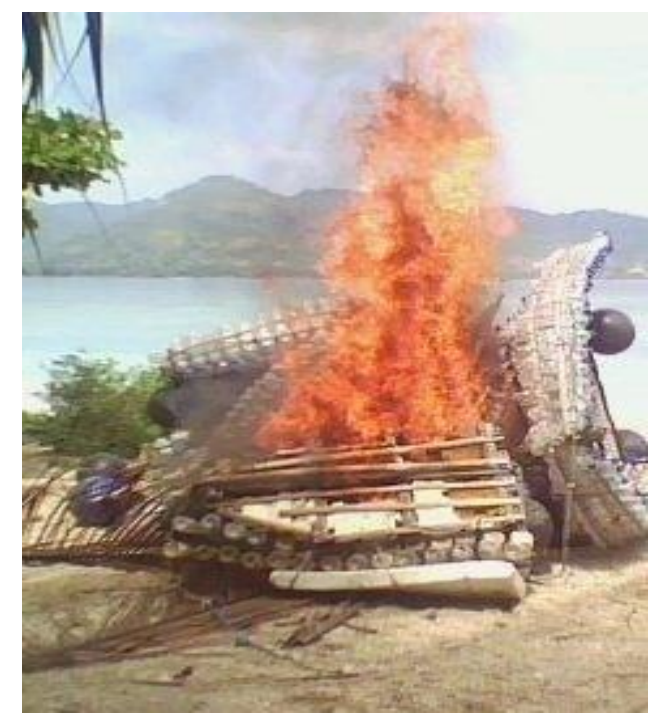

Figure 1. Combustion gear conducting destructive fishing

Society Perceptions of Local Custom. Based on researcher's observations and through in-depth interviews, both with individuals and groups, we obtained a description of a society in coastal areas that showed that Local Custom values, especially concerning the utilization and management of marine and fishery resources, was still an important part of life (Adrianto et al., 2009).

Social Aspirations toward Local Custom. The coastal societies and the fishermen involving in this research had aspirations, concepts, ideas and strong desires to preserve their own Local Custom, customs, and customary law. This aspiration appeared due to the existence of society awareness of the importance of Local Custom as the moral guidance aspects in managing the harmonious relationship between humans and the existing natural resources in their surrounding areas.

Moreover, the society in the research location was still pessimistic and skeptical about the implementation of the formal law, including enforcement officers. Society's response toward the existing and prevailing of positive laws was very low. It was due to the fact that the perpetrators of environmental vandalism were subjected to the unclear investigation and low-deterrent effect punishments.

Opportunities for Local Custom Empowerment. Local custom, traditions, and customary law and traditional institutions in North Lombok Regency could be preserved and nourished by implementing awig-awig as basic regulation of fishery resources and marine management despite the formal law, enabling them to regulate the life and create institutions, norms and the rules related to the coastal and marine resources management. 


\section{DISCUSSION OF RESULTS}

North Lombok's societies not only recognize the territory distribution but also recognize the existence of local regulations which manage the relationships between human and human, society and society, society and the surrounding nature, human and God, or in short, this regulation is called awig-awig or customary law.

In order to fulfill the local regulations, it is also known that there are power and authority distributions into three elements, namely (1) all matters related to Paer village government affairs are controlled by the Pemusungan; (2) all matters related to religious affairs are controlled and administered by Pengulu or Kyai; (3) all matters related to customs are controlled and administered by Mangku.

The Awig-awig prevailing in North Lombok regulates the offshore physical environmental management, such as destructive fishing, waste, coral reef destruction, rare sea biota catches, and zoning distribution (Paer) (Adrianto et al., 2009). Under the rules of the offshore physical environmental management mentioned above, there are prohibitions and sanctions that are stipulated in the agreed awig-awig (Hilmawan, 2012). The zoning distribution/Paer itself is divided into four zones: (1) Zone $A$ is a conservation zone that covers the Gili Indah area and other existing tourism areas in North Lombok; (2) Zone B is the fishing zone using traditional fishing gear that covers the entire area of North Lombok; (3) Zone $\mathrm{C}$ is the aquaculture zone preserved for things such as seaweed and pearls which are located in the villages of Sorong Jukung, Karang Jurang, Papak Indah, Penyambuan, and Medana; (4) Zone D is the fishing zone using traditional fishing gear that its at least $1 \mathrm{~km}$ offshore. By distributing the clear zones, the conflicts that often occur between the fishermen related to the fishing areas can be minimized (Muhyin, 2010).

In the context of the coastal zone management, the role of the traditional institutions along with Local Custom, tradition and customary law had clear strategic opportunities to be exploited in the development efforts toward local people and traditional fishermen. This aspect could be used as means to connect the government's programs and activities and the needs of society. Thus any program that had planned by the government was believed to be implemented precisely to achieve the targets so that impact on the success and sustainability of the program would be maximized. It was based on the premise that whatever the program was, it must fit the needs of local people without contradicted to their local customs in order to develop socio-cultural aspects of the local area itself.

The researcher suggest to keep the local custom value can be preserved and practiced in managing the coastal areas so that make sure the existence and sustainable aquatic ecosystems. The local government also could keeps socializing the coastal areas management to the societies and fishermen by putting onward the local wisdom values. The existence of local people and its local wisdom within needs to be respected and appreciated by the local government as the ancient cultural heritage from generation to generation and to be preserved by releasing a law on local regulations about the local wisdom values so make clear and can minimize the conflicting social which occurs frequently.

This study was revealed the perceptions and aspirations of society toward Local Custom Values is still very strong and is preserved because these values can manage the relationship between humans and the environment so that there will be equilibrium. Local Custom, tradition and customary law as well as customary institutions in North Lombok Regency have the opportunity to be preserved and further developed by implementing awigawig as the basic regulation of fishery and marine resources management, despite the use of formal law, so that they able to regulate the local manner and create institutions, norms, and rules related to coastal and marine resources management.

\section{CONCLUSION}

The perceptions and aspirations of society toward Local Custom Values are still very strong and are preserved because these values can manage the relationship between humans and the environment so that there will be equilibrium. 
Local Custom, tradition and customary law as well as customary institutions in North Lombok Regency have the opportunity to be preserved and further developed by implementing awig-awig as the basic regulation of fishery and marine resources management, despite the use of formal law, so that they able to regulate the local manner and create institutions, norms, and rules related to coastal and marine resources management.

\section{ACKNOWLEDGEMENTS}

The authors are thankful to local communities in North Lombok Regency, especially subdistricts Bayan, Kayangan, Gangga, Tanjung and Pemenang for support this study.

\section{REFERENCES}

1. Adrianto, L., M.A. Al Amin., A. Solihin, D.E. Hartoto, A. Satria. 2009. Local Knowledge and Fishery Management. Center for Coastal and Marine Resources Studies, Bogor Agricultural University. Available at http://aquaticcommons.org/17088/1/005\% 20Local\%20Knowledge\%20and\%20 fisheries\%20management.pdf

2. Hilmawan,A. 2012. Hak Ulayat dalam Ketentuan Hak "Ulayat Right in Right Certainty". Brawijaya University. Malang.

3. LMNLU. 2001. Selayang Pandang Lembaga Masyarakat Nelayan Lombok Utara "Introduction of the North Lombok Fisherman Societies Institute".

4. Muhyin, S. 2010. Buku Lembaga Musyawarah Nelayan Lombok Utara "Book of the North Lombok Fisherman Societies Institute".

5. Satria, A. and D.S. Adhuri. 2010. Pre-existing Fisheries Management Systems in Maluku, Focusing on Lombok and Maluku. In K. Ruddle and A. Satria, editors. Managing Coastal and Inland Waters: Pre-existing Aquatic Management Systems in Southeast Asia, Springer Science+Business Media B.V. DOI 10.1007/978-90-481-9555-8_2.

6. Solohin, A, and Satria, A. 2007. Hak Ulayat di Era Otonomi Daerah sebagai Solusi Pengelolaan Perikanan Berkelanjutan: Kasus Awig-Awig Lombok Utara

7. Stanis, S. 2005. Pengelolaan Sumberdaya Pesisir dan Laut Melalui Pemberdayaan Kearifan Lokal di Kabupaten Lembata, Nusa Tenggara Timur "Management of Coastal and Marine Resource by Empowerment Local Wisom in District Lembata, Nusa Tenggara Timur". Post Graduate Thesis. Diponegoro University. Semarang

8. Steenbergen, DK. 2016. Strategic Customary Village Leadership in the Context of Marine Conservation and Development in Southeast Maluku, Indonesia. Hum. Ecol. Interdiscip. J. 44: 311-327. doi: 10.1007/s10745-016-9829-6

9. Wahyudin, Y. 2004, Pengelolaan Berbasis Masyarakat "Community Based Management". Short Paper. Pusat Kajian Sumberdaya Pesisir dan Lautan. Bogor Agricultural University

10. Yin, RK. 2011.Studi Kasus Desain dan Metode "Case study of Design and Method", Rev Ed. PT Rajawali. Jakarta. 